\title{
THE FEASIBILITY OF UTILIZATION THE VIDEO-CONFERENCE SYSTEMS AT BASIC SCHOOLS IN TERM OF TECHNOLOGY INFRASTRUCTURE
}

\author{
Miroslav $\breve{S} E B O$
}

\begin{abstract}
Video-conference systems represent a great potential in the implementation in educational process. They provide wide area of possibilities to broadcast lectures for more schools at the same time. One teacher, specialist or a group of them can provide a lecture from any place on the Earth simultaneously for practically unlimited number of schools what can save both time and money. The Other advantage lies in possibility of discussion with the lecturer immediately after the lecture. An useful function of video-conference systems is also sharing of the desktop. This means that one student working on PC in one town is able to see the desktop of a teacher's computer in other town. Thanks to this technology with combination of the video-conference system students hava a chance to obtain new information and knowledge in a more interesting way.
\end{abstract}

Key words: video-conference system, technical infrastructure, the Internet.

\section{MOŽNOSTI VYUŽITIA VIDEOKONFERENČNÝCH SYSTÉMOV NA ZŠ Z HLADISKA TECHNICKEJ INFRAŠTRUKTÚRY}

Resumé: Videokonferenčné systémy majú vel'ký potenciál uplatnit' sa vedukačnom procese. Videokonferenčný systém poskytuje možnost’ uskutočňovat' prednášky pre niekol'ko škôl súčasne. Jeden pedagóg, alebo skupina pedagógov prípadne špecialista v danej problematike s hociktorého miesta na Zemi môžu viest' prednášku pre niekolko škôl súčasne, čo ušetrí školám čas aj peniaze a žiaci môžu diskutovat's prednášajúcim okamžite po ukončení prednášky.

Užitočnou funkciou videokonferenčných systémov je zdiel'anie pracovnej plochy. To znamená že napr. žiak sediaci za počitačom vjednom meste, môže vidiet’ pracovnú plochu v počitači pedagóga sediaceho v inom meste. Pomocou tejto technológie v kombinácii s video konferenciou si žiaci môžu zaujímavým spôsobom osvojovat' nové vedomosti.

Klíčová slova: Technická infraštruktúra, siet' Internet, videokonferenčný systém.

\section{1 Úvod}

Za účelom zistenia stavu prípravy učitel'ov na využívanie moderných technológií vo výučbe bol na Katedre techniky a informačných technológií PF UKF v Nitre riešený projekt Kega s názvom „Overenie videokonferenčného systému a dištančných technológií v aplikáciách“. Na zistenie stavu technického vybavenia škôl bol vytvorený neštandardizovaný dotazník. Dotazník je zameraný na zistenie a posúdenie kompetencie učitel'ov vzhl'adom $\mathrm{k}$ ich profesii - špecificky na pedagogickú prax a videokonferenčné systémy. $\mathrm{Na}$ základe vyhodnotenia výsledkov z dotazníka, kolektív riešitel'ov pristúpil v roku $2011 \mathrm{k}$ plneniu prvého a druhého ciel'a výskumného projektu a to:

- stanovenie štandardu vedomostnej úrovne a praktických zručností na využívanie videokonferenčného systému a dištančných technológií učitel'mi,

- vymedzenia minimálnych technických a organizačných požiadaviek pre úspešné využívanie týchto systémov učitel'mi.

$\mathrm{V}$ našom článku sa budeme podrobnejšie zaoberat' druhým ciel'om projektu

\section{Technické podmienky pre realizáciu}

$\mathrm{Na}$ správne fungovanie videokonferenčného systému VRVS/EVO, musí PC spíňat' nasledovné požiadavky:

- Intel a AMD PC: aspoň 2 jadrový procesor, 2 GB RAM s WindowsXP/Vista/Seven alebo Linux

- Macintosh s Intel procesorom s 1 GB RAM s Mac OSX 10.4 alebo vyšším. 
Taktiež musí byt' zaistenie dostatočnej priepustnosti siete pre príjem/vysielanie dobrého video/audio signálu.

Autori VRVSV uvádzajú v publikácii [1] nasledujúci príklad:

Garantovaná kapacita siete je 1024Kbit/s. Videokonferencie sa zúčastňuje 15 partnerov. Každý vysiela kvalitný obraz (s datovými tokmi okolo $800 \mathrm{Kbit} / \mathrm{s})$. Kapacita siete by teda mala byt' aspoň $12 \mathrm{Mbit} / \mathrm{s}$ :

Počet učastníkov x $800 \mathrm{Kbit} / \mathrm{s}+64 \mathrm{Kbit} / \mathrm{s}$ (minimálny audio tok)

$(15 \times 800+64) \mathrm{Kbit} / \mathrm{s}=12064 \mathrm{Kbit} / \mathrm{s}$.

$\mathrm{Na}$ komunikáciu $\mathrm{s}$ inými účastníkmi a príjem/vysielanie dobrého video a audio signálu cez EVO, musí siet'ové pripojenie splnit' nasledovné minimálne požiadavky (predpokladáme že $384 \mathrm{kbps}$ je dostatočné na zabezpečenie vel'mi dobrej obrazovej/audio kvality): $384 \mathrm{kbit} / \mathrm{s}+64 \mathrm{kbit} / \mathrm{s}=448 \mathrm{kbit} / \mathrm{s}$ rýchlost' st'ahovania (download speed) pre každého $\mathrm{z}$ účastníkov od ktorého prijímame video a audio (t.j. pri dvoch externých účastníkoch potrebujeme rýchlost' st'ahovania $2 \mathrm{x}$ $448 \mathrm{kbit} / \mathrm{s}=896 \mathrm{kbit} / \mathrm{s}$ ), pokial' neaktivujeme "Voice switch" (,hlasový prepínač“) režim (pri tomto režime prijímate iba video od práve hovoriaceho účastníka). $448 \mathrm{kbit} / \mathrm{s}$ rýchlost' vysielania (upload speed) (pre každú EVO stanicu v sieti z ktorej chcete vysielat' dobrý video a audio stream). [2]

\section{Realizácia projektu}

Dotazník pre učitel'ov bol v elektronickej forme zadávaný učitel'om cez EduTech portal webovú lokalitu spravovanú pracoviskom Katedra techniky a informačných technológií v Nitre.

Štatistické spracovanie dotazníkov sa uskutočnilo v programe Excel.

Dotazník vyplnilo 148 pedagógov so základných a stredných škôl. Z toho 131 pedagógov bolo zo základných škôl, 51 z gymnázií, 1 zo strednej odbornej školy a jeden zo špeciálnej školy.

Tabul'ka 1: Počet rokov praxe v školstve

\begin{tabular}{|c|c|}
\hline Počet rokov & Počet pedagógov \\
\hline do 5 & 3 \\
\hline 6 do 10 & 20 \\
\hline 11 do 15 & 32 \\
\hline 16 do 20 & 27 \\
\hline nad 20 & 66 \\
\hline
\end{tabular}

Graf 1: Počet rokov praxe

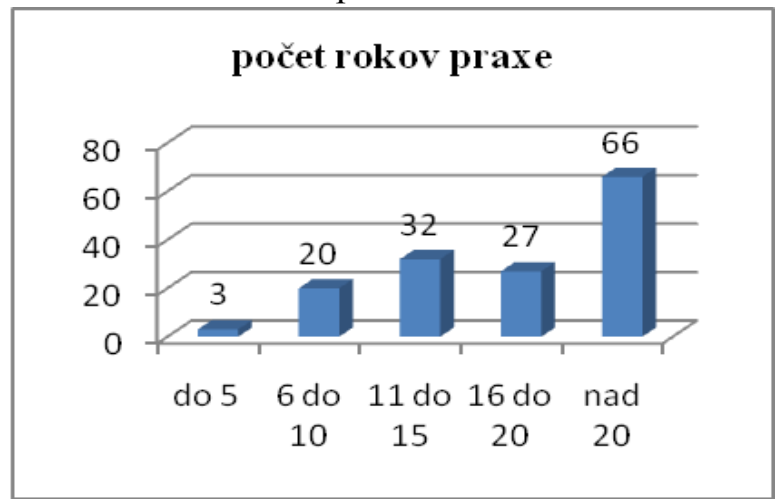

Tabul'ka 1 a graf 1 pojednávajú o respondentoch $\mathrm{z}$ hl'adiska počtu rokov praxe v školstve, kde 66 respondentov, čo predstavuje viac ako 44\%, má pedagogickú prax nad 20 rokov.

V d'alšej časti dotazníka sme za zamerali na technické vybavenie škôl a to najmä na vybavenie umožňujúce využívanie videokonferenčných systémov vo vzdelávaní a na typy pripojenia škôl k sieti Internet. Zaujímalo nás predovšetkým, aké rýchle pripojenie $\mathrm{k}$ sieti Internet školy majú, lebo na základe rýchlosti prijímania a odosielania dát je, alebo nie je možné využívat' videokonferenčné systémy vo vzdelávaní.

Zo všetkých 148 respondentov má v škole prístup k sieti Internet až 146 respondentov, čo je prvý krok k možnosti využívania videokonferenčných systémov. Ďalšou podmienkou pripojenia k sieti Internet je jej rýchlost' prenosu údajov oboma smermi. Touto podmienkou sa zaoberali otázky 6 a 7 dotazníka, ktoré zneli:

- Akú rýchlost' pripojenia $\mathrm{k}$ sieti Internet má Vaša škola (DOWNLOAD - st'ahovanie zo siete Internet)?

- Akú rýchlost' pripojenia $\mathrm{k}$ sieti Internet má Vaša škola (UPLOAD - odosielanie do siete Internet)?

Vyhodnotenie týchto otázok sa nachádza v tabul'kách 2 a 3 a v grafoch 2 a 3 .

Tabul'ka 2: Rýchlost' prijímania dát (download) Rýchlost' - download Počet pedagógov

\begin{tabular}{|c|c|}
\hline $2 \mathrm{Mb} / \mathrm{s}$ a viac & 21 \\
\hline $512 \mathrm{~kb} / \mathrm{s}-2 \mathrm{Mb} / \mathrm{s}$ & 22 \\
\hline $256 \mathrm{~kb} / \mathrm{s}-512 \mathrm{~kb} / \mathrm{s}$ & 17 \\
\hline $128 \mathrm{~kb} / \mathrm{s}-256 \mathrm{~kb} / \mathrm{s}$ & 14 \\
\hline $64 \mathrm{~kb} / \mathrm{s}-128 \mathrm{~kb} / \mathrm{s}$ & 10 \\
\hline neviem & 64 \\
\hline
\end{tabular}


Graf 2: Rýchlost' prijímania dát (download)

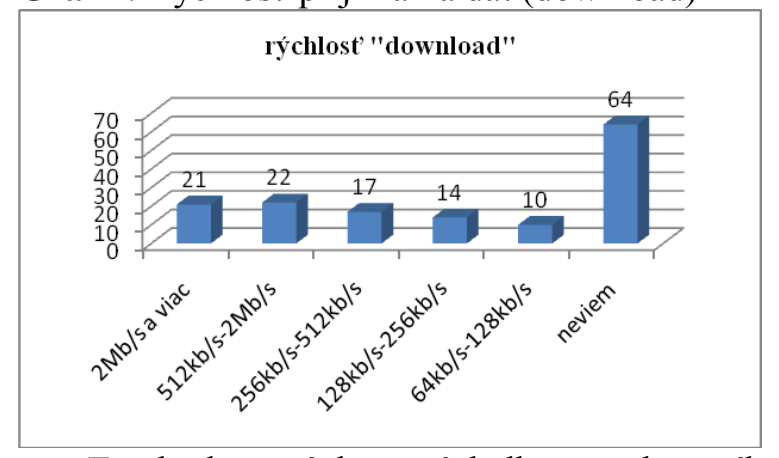

Z vyhodnotených výsledkov dotazníka (tabul'ka 2 a graf 2) na otázku 6 o rýchlosti pripojenia $\mathrm{k}$ sieti Internet (download) nevyplýva jednoznačný záver, aké rýchlosti prijímania dát školy majú, a to $\mathrm{z}$ dôvodu vel'kého počtu odpovedí „neviem“. $\mathrm{Na}$ používanie videokonferenčného systému je potrebné pripojenie $\mathrm{s}$ rýchlostou prijímania dát ideálne 2 $\mathrm{Mb} / \mathrm{s}$ a viac, $\mathrm{v}$ krajnom prípade $512 \mathrm{~kb} / \mathrm{s}-2 \mathrm{Mb} / \mathrm{s}$. Túto podmienku však spín̆alo len 43 respondentov, čo predstavuje $29 \%$ respondentov.

$\mathrm{Na}$ otázku číslo 7 , ktorá pojednáva o rýchlosti odosielania dát (upload) respondenti odpovedali tak, ako je uvedené v tabul'ke 3 a grafe 3 .

Tabul'ka 3: Rýchlost' odosielania dát (upload)

\begin{tabular}{|c|c|}
\hline Rýchlost' - upload & Počet pedagógov \\
\hline $2 \mathrm{Mb} / \mathrm{s} \mathrm{a} \mathrm{viac}$ & 11 \\
\hline $512 \mathrm{~kb} / \mathrm{s}-2 \mathrm{Mb} / \mathrm{s}$ & 20 \\
\hline $256 \mathrm{~kb} / \mathrm{s}-512 \mathrm{~kb} / \mathrm{s}$ & 21 \\
\hline $128 \mathrm{~kb} / \mathrm{s}-256 \mathrm{~kb} / \mathrm{s}$ & 16 \\
\hline $64 \mathrm{~kb} / \mathrm{s}-128 \mathrm{~kb} / \mathrm{s}$ & 10 \\
\hline $\mathrm{Neviem}$ & 70 \\
\hline
\end{tabular}

Graf 3: Rýchlost'odosielania dát (upload)

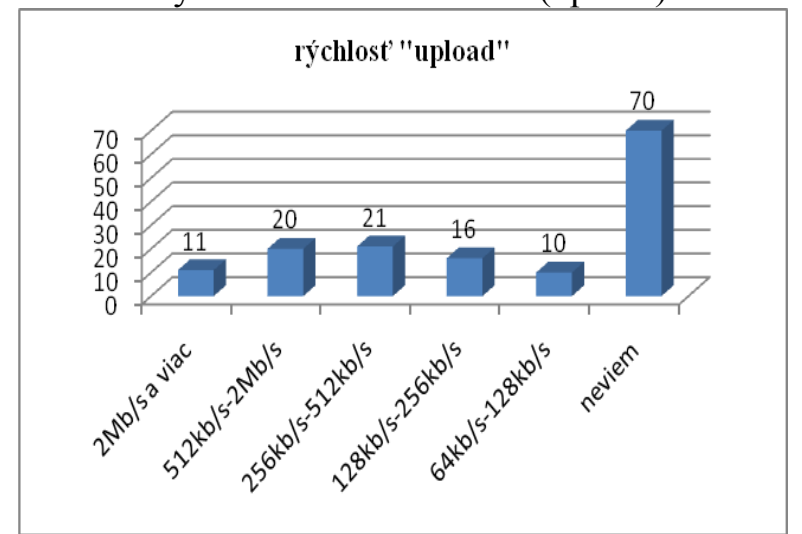

Výsledky na otázku číslo 7 sú podobné výsledkom na predchádzajúcu otázku. Aj v tejto otázke odpovedalo vel'a respondentov odpoved'ou „neviem“, čo vel'mi skresl'uje celkovú štatistiku. Rýchlost' potrebná na spol'ahlivé používanie videonferenčného systému je minimálne $512 \mathrm{~kb} / \mathrm{s}-2 \mathrm{Mb} / \mathrm{s}$, ideálne však viac ako $2 \mathrm{Mb} / \mathrm{s}$. Túto podmienku však splnilo iba 31 respondentov, čo predstavuje necelých 21 $\%$ všetkých respondentov.

Dalšia otázka dotazníka smerovala na zistenie, či majú školy dátovo obmedzený prístup $\mathrm{k}$ sieti Internet. Táto otázka bola dôležitá , lebo pri využivaní videokonferenčného systému sú po sieti Internet prenášané vel'ké množstvá údajov. $\mathrm{Na}$ túto otázku odpovedalo 139 respondentov, čo predstavuje $94 \%$, odpoved'ou „nie“, to znamená, že prevažná väčšina škôl má dátovo neobmedzený prístup $\mathrm{k}$ sieti Internet.

Respondentov sme sa tiež pýtali, či majú absolvovaný kurz ECDL (vodičák na počítač). $Z$ výsledkov dotazníka vyplýva, že len 35 respondentov, čo predstavuje $24 \%$, má tento certifikát. $Z$ celkového počtu 35 respondentov má 22 respondentov ECDL certifikát prax $\mathrm{v}$ školstve viac ako 20 rokov. ECDL certifikát je dôležitým certifikátom, ktorý zaručuje určitú vedomostnú úroveň respondentov $\mathrm{z}$ oblasti informačnokomunikačných technológií.

V d'alších otázkach sme sa zamerali na technické vybavenie počítačov, potrebné na videokonferenčné systémy. Otázky zneli nasledovne:

- Je aspoň $\mathrm{k}$ jednému počítaču na škole pripojená web kamera?

- Má táto web kamera mikrofón?

- Je $\mathrm{k}$ počítaču pripojený externý mikrofón?

- Máte na škole dataprojektor?

$\mathrm{Na}$ otázku: Je aspoň $\mathrm{k}$ jednému počítaču na škole pripojená web kamera? odpovedalo $53 \%$ respondentov ,áno“. Tento údaj je na dnešné pomery a ceny web kamier dost' prekvapujúci a predpokladali sme, že web kamier bude na školách podstatne viac. Bez základného vybavenia ako je web kamera nie je možné aktívne pracovat' vo videokonferenčných systémoch a takýto účastník je odkázaný na úlohu pasívneho poslucháča. $\mathrm{Na}$ to aby sa účastníci videokonferencie mohli aktívne zapájat' do diskusie je okrem web kamery potrebný aj mikrofón. Mikrofón môže byt' externý, alebo integrovaný vo web kamere. Respondentov sme sa preto pýtali či ich web kamera obsahuje mikrofón. Z celkového počtu 79 web kamier má len 55 web kamier integrovaný mikrofón.

Počet respondentov, ktorí majú k svojmu počítaču pripojený externý mikrofón je zobrazený $\mathrm{v}$ tabul'ke 4 a grafe 4 . Z celkového 
počtu 148 má len 46 respondentov externý mikrofón. Respondentov, ktorý majú web kameru bez mikrofónu, ale majú externý mikrofón je 13.

Tabul'ka 4: Externý mikrofón

\begin{tabular}{|c|c|}
$\begin{array}{c}\text { Je k počítaču } \\
\text { pripojený externý } \\
\text { mikrofón? }\end{array}$ & $\begin{array}{c}\text { Počet } \\
\text { pedagógov }\end{array}$ \\
\hline áno & 46 \\
\hline nie & 81 \\
\hline neviem & 21 \\
\hline
\end{tabular}

Graf 4: Externý mikrofón

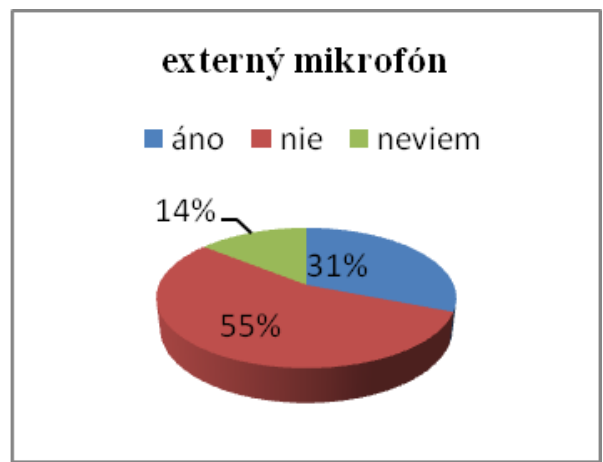

Ďalšia otázka zist'ovala, či sa v školách nachádza dataprojektor. Dataprojektor je dôležitým komponentom vo videokonferenčných systémoch. Jeho úlohou je zobrazit' vysielaný a prijímaný obraz na vel'kej ploche pre čo najväčšie publikum. To, že dataprojekror má 145 škôl, čo predstavuje $98 \%$, je pozitívna informácia a poukazuje na to, že školy sú v tejto oblasti na videokonferenčné systémy pripravené. Paradoxom však je, že $98 \%$ škôl má dataprojektor v hodnote niekol'ko $100 €$, ale len 53 \% škôl má web kameru, ktorej cena je rádovo niekol'ko desiatok eur.

\section{Záver}

Minimálne technické požiadavky potrebné na zabezpečenie úspešného využívania moderných videokonferenčných aplikácií v pedagogickej praxi boli navrhnuté na základe výsledkov vyhodnotených dotazníkov a komparáciou optimálnych návrhov teoretických prác odborníkov.

Z výsledkov dotazníka vyplýva že skoro 50 \% škôl nemá web kameru, alebo mikrofón. Pripojenie väčšiny škôl $k$ sieti Internet je na využívanie videokonferenčného systému nedostačujúce. Z týchto dôvodov môžeme konštatovat' že približne $50 \%$ škôl nespĺn̆a minimálne technické požiadavky potrebné na zabezpečenie úspešného využivania moderných videokonferenčných systémov $\mathrm{v}$ pedagogickej praxi.

\section{Literatura}

[1] P. Farkas, M. Pauliny, V. Michalcin, M.

Domarack, and M. Kankula.

Jednoduchý návod ako použivat' VRVS

videokonferenčný systém, [online], [2011-06-

06] Dostupné na internete:

http://vk.upjs.sk/stranky/technology/videostre am/VRVS.pdf.

[2] Základy práce s konferenčným systémom EVO, [online], [2011-06-06] Dostupné na internete: www.cvtisr.sk/index/open_file.php?file $=\mathrm{NCP} /$ navod_evo.pdf 6.6.2011, 16:00

Mgr. Miroslav Šebo, PhD.

Katedra techniky a informačných technológií

Univerzita Konštantína Filozofa v Nitre

Pedagogická fakulta

Dražovská cesta 4,

94974 Nitra

e-mail: msebo@ukf.sk 